\title{
A Small Credit would be an Essential Instrument to Urban-Rural Development
}

\author{
Bhakta Kumar Puri*, Kazuo Takahashi \\ Graduate school of Regional development study, Toyo university, Tokyo Japan
}

*Corresponding Author: Bhakta Kumar Puri, Graduate school of Regional development study, Toyo university, Tokyo Japan

\begin{abstract}
The research paper talks about urban-rural development through small credit in Nepal. The prime development tools of urban-rural are small credit known as microcredit. The research-based on NGO (Lumanti) organized an urban-rural community called Dibyajyoti women Saving and a credit (DWSCC) established in 2003. It has been providing the small credit to the Urban-rural poor for an escape from poverty and community development. The research paper aims to find out the impact of Small credit in upgrading the living situation of poor with using the questionnaire survey, case study, and focus group discussion. The research result indicates that Urban-rural poor people can enhance their quality of life. The financial and technical support by the Lumanti NGO Role is crucial to organize the community together. The small saving and credit do not only provide financial access to poor people also built social capital and collective action for their community upgrading and social development. However, the community member is facing the same challenges in management as well as does not correctly using the credit.
\end{abstract}

Keywords: Small credit for community development/ credit and urban rural community development/ credit as an instrument for urban-rural community development

\section{INTRODUCTION}

Nepal is the poorest country in the world. A member of the least developed countries (LDCs) for many years. According to the UNDP human development reports 2014, Nepal has 145 positions out of the 187 in terms of human development (Global South Magazine 2019).Nearly $75 \%$ of the population living in village "over $90 \%$ population live in rural" In urban areas, the poverty incidence is almost $23 \%$ which is significantly lower than in rural areas. Poverty is a common issue for developing countries. Nepal is the poorest country in South Asian. The National per capita income of Nepal is near $\$ 1002$ (UNDP 2018) More than 71\% of the population relies on agriculture, and $15 \%$ of that population lives below the poverty line (PPP 1.90 a day). Nepal, a developing south Asian country, is challenging the problem to overcome poverty. However, $24.3 \%$ of the population lives in multidimensional $^{\text {(notel) }}$ poverty (UNDP 2018).

Most of the third world countries are facing the challenges of extreme poverty, inequalities, social inclusion gender gap, and much more. The leading causes of increasing -urban poverty is rural-urban migration, political instability, civil war, seeking a better opportunity: a political conflict or civil war affecting the people mobilization. In Nepal, the civil war between 1996-2006 has destroyed the peace of society, mainly the rural area of Nepal. During the civil war period, an estimated 100,000 to 150,000 (Basnett 2004) people internally displaced as a result of the conflict. Rural people have disconnected from government facilities and development activities. That so-called civil war has played a crucial role in creating urban-rural poverty. In the context of Nepal, to address the above mention, everyday issues of the community, in the collaboration of the Lumanti NGO and ACCA (Asian collation for community Action), ACHR (Asian community housing rights) started the community finance projects in 1996. Lumanti ${ }^{\text {(NOTE } 2)}$ (Lumanti Support Groups for Shelter), was established in 1993 to support urban imperfect community development process that has started from capital city Kathmandu and expanded over Nepal.

ACHR supported Lumanti to established the community finance ${ }^{(n o t e)}$ is also call saving and credit groups, which is more or less similar to the microfinance but different in practices. In 1997 the first saving and credit groups were established in three settlements in Kathmandu, where the women began 
to save five NRs per month in a common fund. The positive result of Kathmandu encouraged to expand in other places of Nepal. And then started in the eastern region of Nepal at Dharan. This research objective is to visualize the community finance and the role of urban, rural development practices in Nepal with microcredit or community finance. Microcredit is a part of the microfinance and which refers to the tiny lone. The word credit develops from the Latin word 'credo '. It means I believe or trust (D Kumar, A Hossain, MC Gope 2012) lenders believe the borrower and provided the loans with the believe and trust. Theoretically, microcredit is for income-generating activities, self employment, and other creative activities to the poor and low-income community.

In 1976 Revitalizing of the Grameen Bank (Village bank) in Bangladesh by Prof. M Yunus than the concept has changed (Handbook of microfinance 2011 p 5). The idea of the Grameen bank become popular all over the world. The classic model of M. Yunus in Bangladesh, the Grameen bank model, has significantly contributed to poverty reduction and rural development in Bangladesh. before 1990, the microcredit provided to the group loans with social collateral or all the group member was equally responsible for the loans. M Yunus (2010) argues that the rural poor are deprived of the financial service and depend on the informal financial services at that time. Grameen bank concept was conceptualized by the Yunus, has played a significant role in changing the miserable rural life.

Elizabeth Littlefield, Jonathan Murduch, and Syed Hashemi (2003) emphasis on the poor people use the financial services for both business investment of microenterprises and the health, education, and the to manage the household emergencies and other various purposes of their needs. They state that small credit strongly supports to meet the millennium development goals. Credit is self could define a small amount of money or fund. Microfinance covers a wide range of financial services. Habib and Job 2012, lexLoro 2013 p1) emphasis that the significant improvement of women's socio-political status due to microcredit. Microcredit has been playing a significant role and a powerful tool for poverty reduction. Like many other development tools Jonathan Murdoch and Barbara Haley (2001), Microfinance and microcredit are the tools which brought a revolutionary change in the life of women, engage the women in communal activities, having the small loan participate in incomegenerating, empowerment activities, and the group system made them strong. The formal financial intuition does not provide small loans without the collateral to the poor people M Yunus (2010). The poor people have not any collateral and have no grantee to repay the loan. The banks and financial intuition do not believe to low-income people. In this context, a microfinance institution serves the poor and provided the small loan for income-generating activities. Thus, Yunus (2010) called the microfinance is the bank of the rural poor; it provided the financial service to the rural and urban poor without the collateral.

\section{URban-RuRal DeVElopment With CREDit}

Rural development is a broad term different than the development of other types of development. Rural development itself define as development in the low-density area less accessible and dominant by agricultural rich in natural resources. According to the World Bank, (1975), rural development is defining as "a strategy aiming at the improvement of economic and social living conditions, focusing on a specific group of poor people in a rural area. It assists the poorest group among the people living in rural areas to benefit from development".

In third world countries, rural development is avoiding, or the government has limited natural resources to distribute the small budget. The rural development process to improve the quality of life through economic access for the rural poor. The rural poor live in an isolated situation. The need for rural communities to approach development from a wider perspective has created more focus on a broad range of development goals rather than merely creating an incentive for agricultural or Rural development - resource-based businesses.

The microcredit or small credit is an essential tool for poverty and community-based development. The rural development budget and subsidies of developing counties could not be enough to improve the education quality, development of infrastructure, and social development. A small credit and community Driven financial subsidies could be playing a significant role. The empirical research tries to investigate the role of small credit in the Urban-Rural community development aspect in Nepal and strategies to introduce the credit role in developing the leadership and social capital of participants as well as the impacts of community-driven development practices in Nepal. 
The objective of the research is to find out the role of small credit in urban, rural community development. The specific objective of the paper investigates the economic accessibility and development of the social capital of the participants on the DWSCC. The In-depth interview and case study held with participants in their location village and their saving and credit office and the place of work and where the in-depth interview conducted on a regular monthly gathering day. All the community members invited to that meeting and interviewed using the structured questionnaire in their natural setting of meeting. Focus group discussion was organized in the weekly meeting day at their DWSCC office. The observation was conducted in the community for two weeks. The secondary data of this paper has been collecting from different sources, such as previous researches, Books, newspapers, articles, journals as well other related published and unpublished materials, which play a significant role in the to develop the concept.

The research organized in DWSCC. Behind to select the DWSCC, there is not existing previous academic research, and the second reason select is an ideal type of microcredit mechanism which is more effectively active in that community. Not only for financial services also for Urban-rural development. The research target groups are the poor and low-income communities. The selected community has a different characteristic, such as slum squatter, low-income labors. Community-based finance organizes in the slum and squatter community where the respondents are living in urban and rural areas under the poverty line (Income less than 1.90 \$ a day UNDP 2017). The target groups of the research were the low income and deprived of the necessary human facilities.

\section{Dib YAJYoti CREDIT CO-OPERATIVES}

Dibyajyoti is a woman saving and credit (DWSCC) situated in the eastern part of Kathmandu, Sunsari Dharan sub-metropolitan city ward nine, Nepal, in provision one. It established in 2059 BS/ 2003 AD in support of Lumanti support groups of shelter. Having 66 groups and the characteristic of the community is a Squatters community where the people are living Urban, rural side by occupied the land. The total number of saving and credit co-operatives member are 1298. The prime objective of the community-based saving and credit is to establish the social capital with gathering the scattered community members in a community with making small saving mechanism and together for community development that makes significant social capital.

The collected capital can borrow by the community member for income generation, and secure their future, improve their quality of life in 2012 DWSCC awarded as the best saving and credit cooperative award. The women-based community has started to do saving with NRs 2 per day or Nrs 60 per month. Now, they are saving 100- 2000 Nrs per person. The community has a robust social bond as a landless and squatter community. The DWSCC has been providing a small loan to the member for housing (low-interest rate) income-generating a loan, and another type of loan like household expenses loan, child education loan, as well as the other loan which in demand of the member. The repayment rate of the community-based saving is 99 percent, and all the members are a compulsory saving member.

\section{THE RESEARCH FINDINGS}

According to the findings, the total number of respondents was 25 the members of small saving and Credit co-operatives - age between the 10-60 years old 'respondents' women. The respondents have divided into five different age groups 10-19, 20-29, 30-39,40-49, 50-60, and older than 60 years the highest number of respondents aged between 30-39 and the lowest number of respondents age above 50 (Table 1).

Table1: Demographic information

\begin{tabular}{|l|l|l|l|}
\hline \multicolumn{1}{|c|}{ Age groups } & \multicolumn{1}{c|}{ No. } & \multicolumn{1}{c|}{ Marital status } & No. \\
\hline $10-19$ & 0 & Married & 23 \\
\hline $20-29$ & 2 & Unmarried & 0 \\
\hline $30-39$ & 19 & Divorced & 2 \\
\hline $40-49$ & 3 & Total & 25 \\
\hline $50>$ & 1 & & \\
\hline Total & $\mathbf{2 5}$ & \multicolumn{1}{|c|}{ Education } & \multicolumn{2}{|}{ No. } \\
\hline \multicolumn{1}{|c|}{ Gender } & No. & Illiterate & 9 \\
\hline Male & 0 & Primary & 10 \\
\hline Female & 25 & & \\
\hline
\end{tabular}




\begin{tabular}{|l|l|l|l|}
\hline Total & 25 & Secondary & 6 \\
\hline & & High school & 0 \\
\hline & & Total & 25 \\
\hline
\end{tabular}

Sources: Field Visit 2018

The research result indicates (Table 1) that among the total respondents, 23 respondents married, and none of the respondents are single. 2 respondents are divorced or separated single living life. The research reveals that microcredit member has a low level of education illiterate respondents are nine, and ten respondents have only primary school similarly higher educational respondents are $\mathrm{o}$ continuously the secondary level of education respondents is 6 . The findings reveal that most of the participants are the female household head. The research examines that most of the respondents are illiterate or they have no education. Education plays an essential role in community finance to direct the right way. The research observes that the level of education, the borrower has been facing a lack of knowledge to utilize the loan in productive sectors. Some respondent has replied sometimes they met the problem of management and planned because all of them are uneducated.

\subsection{Occupation of the Respondents}

The research result show that (Table-2) respondents' income sources are various such as monthly salary, labor, and self-employ. The research data shows 3 respondents have monthly salary works, and 8 participants are doing daily income labor such as construction labor, waste worker. In the same way, six respondents are engaging in self income-generating activities. Nearly half of the respondents do not want to mention their income sources.

Table2: Occupation of the respondents

\begin{tabular}{|l|l|}
\hline \multicolumn{1}{|c|}{ Occupation } & \multicolumn{1}{c|}{ No. } \\
\hline Monthly salary work & 3 \\
\hline labour & 8 \\
\hline Self employed & 6 \\
\hline Not replied & 8 \\
\hline Total & 25 \\
\hline
\end{tabular}

Sources: Field Visit 2018

The findings indicate that the respondent's income sources and income level show that the respondents are low-income disadvantaged groups who are under the poverty line. Monthly income is still in a critical situation but compares to the past, the quantitative result and case study show that the condition of poverty has been improving. The observation and case study found that the knownreplied respondents are working in high-class family household work, so they do not want to respond because they thought it is a low-level work in society.

\subsection{Respondent Purpose of Borrowing}

The research found (Fig.3) that the clients use a small credit as the mechanism of financial access. The purpose of the loans reveals that the highest amount of borrowing trend is for Small incomegenerating purposes $\mathrm{N}=14$, and the second-highest purpose of the loan is for child education $\mathrm{N}=9$ and household expenses $\mathrm{N}=5$. The lowest purpose of the loan to return the loan amount $\mathrm{N}=4$.

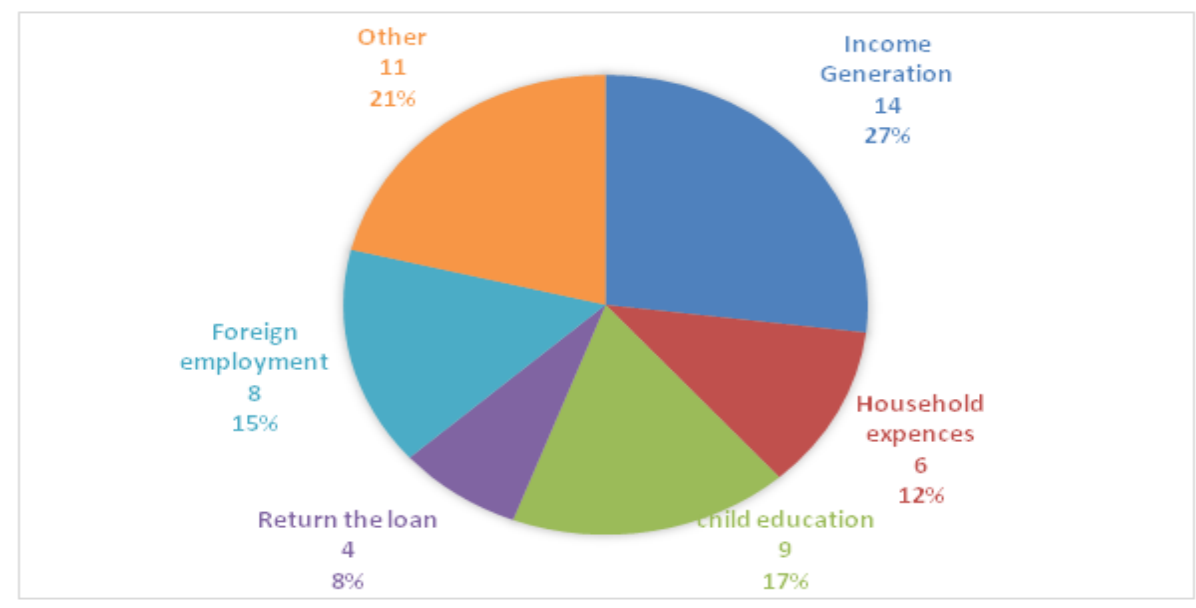

Fig1 
Sources: Field Visit 2018 by the Researcher

Another highest trend of the borrowing is different employment purposes $\mathrm{N}=8$ the previous data shows that every year foreign employment lone has been increasing highly. At the same time, 9 of the respondents have replied to the other, that others represent the housing loan at a low-interest rate. Most of the community-led finance under the Lumanti has supported by the international organization for the secure shelter to low-income people, so many borrowers or participants being able to change their insecure housing to secure housing.

\subsection{Income of Respondents Before and After}

Table3: Income of respondents before and after

\begin{tabular}{|l|l|l|}
\hline Income & Before & After \\
\hline Less $<5,000$ & 16 & 6 \\
\hline $6,000-10,000$ & 6 & 11 \\
\hline $11000-15000$ & 0 & 6 \\
\hline $16000>$ above & 0 & 2 \\
\hline Non-Respondents & 3 & 3 \\
\hline Total & 25 & 25 \\
\hline
\end{tabular}

Sources: Field Visit 2018 by the Researcher

The income level of the respondents before participation in saving and credit co-operatives was deficient (Fig4). Sixteen respondents have replied their income was less than NRP 5000 per month. Six respondents have replied that their monthly income was between NRP 6,000-10,000 Monthly. Three respondents have not replied to their income level ad; there are no respondents have income over 11 thousand before to involve in the community organized financial activities.

In the same way, involving in saving \&credit, the income of the participants has increased compared with the past. After the participation in microcredit, none of the participants have income less the Nrs 5000 and 74 respondent has Nrs 6000-10000, and the 19 respondents have over Nrs 11,000, and three respondents have more than Nrs 15,000 monthly income (Fig 4). The key findings of the income index indicate the period of participation and increase in the income has interrelationship. The research result shows that long-term participating members' income is higher than the short period participant. The qualitative findings and quantitative findings result are the same, and both results indicate that the income of the long period of participants is higher than the short period of participants.

The income of the respondents has been increased compared with the past, but this paper could not confirm that change in the income ratio could not be the only impacts small credit there might be role or other factors too such as foreign employment. However, access to microcredit itself is essential for poor people. The access to small credit to the urban and rural poor brings considerable change such as access the finance services that support to solve the participants emergency issue, able to make them self-employ, be able to build the secure housing, be able to send their children to school for education and support in build social capital in community level, in household level, and community level.

\subsection{The Perception of Participants}

The microcredit played an essential role in building the decision-making capacity of the respondents compared with the past. The participants' women's decision-making capacity has increased (Table -4). Respondents strongly agree that after the participate in microcredit, the different factors impacted to build the capacity of decision making, for example, monthly meetings, different capacity building training, and the networking system (sharing and learning) activities are more supportive of improving the decision-making capacity of the participants. Table 4 shows that 15 respondents strongly agree, and 6 of them only agrees, and the three respondents neither agree nor disagree that microfinance impacts in development in the decision-making capacity of the participants. However, the observation and case study result shows that the decision-making capacity of participants has not changed, and still, the household head is male, and decisions also made by the husband.

Table4: The perception of respondents

SA-strongly disagree, $\mathrm{A}=$ Agree, $\mathrm{N}=\mathrm{Neutral} \mathrm{DA}=$ Disagree SDA= strongly Disagree

\begin{tabular}{|l|l|l|l|l|l|l|}
\hline S. N & Questions & SA & A & N & D A & S DA \\
\hline Q1 & Micro credit support to increase the income? & 18 & 3 & 2 & 0 & 0 \\
\hline Q2 & After the participant in Co-operatives decision-making capacity increase? & 15 & 6 & 3 & 1 & 0 \\
\hline Q3 & Microcredit support to reduce Poverty? & 18 & 2 & 2 & 2 & 2 \\
\hline
\end{tabular}




\begin{tabular}{|l|l|l|l|l|l|l|}
\hline Q4 & Participation in Co-operatives support in women empowerment? & 13 & 3 & 8 & 3 & 0 \\
\hline Q5 & Participation in Co-operatives support in child education? & 14 & 6 & 3 & 4 & 0 \\
\hline Q6 & It is easy to get Loan from the Co-operatives & 13 & 6 & 4 & 5 & 1 \\
\hline Q7 & Participation in co-operatives support in leadership development? & 13 & 6 & 4 & 6 & 1 \\
\hline Q8 & Does participation in community bases finance support in family health? & 10 & 8 & 4 & 2 & 0 \\
\hline
\end{tabular}

Sources: Field visit 2018 by the Researcher

The research found, the low-income people, participating in small credit, has brought a massive change in economic income as well as social capital and urban community development aspects of the participants. Microcredit mechanism ensure equal participation and it is essential aspects of urbanrural development. The DWSCC is not only providing the financial services to the local people together providing the community-based development activities such as the improvement of the safe drinking water system, secure housing, and the construct the toilet facilities in each household as well as women empowerment activities which have positive support in the urban-rural community development. The DWSCC is adopting a different type of financial services and also facilities other different empowerment services as well as the leadership development services to the community participants. Participation is another important mandatory rule of DWSCC. To develop the leadership capacity to the community member self-help and self-organize for and self-regulate and participation is the leading aspect of that community.

Thus, this system support to build leadership capacity. Thirteen respondents strongly agree with microcredit help to develop leadership capacity. Six respondents only agree, and four respondents are neither agreed nor disagreed that the role of community finance in leadership development. Single respondents disagree entirely, and six respondents who sharply disagree with small credit could not play an essential role in leadership development. Qualitative findings and quantitative findings show that access to microcredit has positively supported in empowering and playing a crucial role and leadership development aspects (Kabeer 2005). The findings of the research show that microcredit is a vital tool to reduce poverty and urban-rural community development. Small credit in south Asian countries has improved the economic condition of the poor. A study found that the economic situation of women and low-income squatter community have improved compared to the past (Naila Kabeer 2005 EPW). The research paper found that all the microfinance institutions in Nepal are supporting rural and urban community development. In the end, the research's overall research finding shows that economic access to the low income and Urban-rural poor is an essential aspect.

Financial sustainability perspective which emphasis on sustainable of the intuition do not concern to the poverty reduction and development in the remote rural area as well as could not support the poor and in poverty reduction and community development. The evidence of this research indicates that somehow, access to microcredit changes the living situation of poor and low-income people as well as providing the financial services too. The research result emphasis that economic access and collective action could play a decisive role in rural-urban development.

\section{CONCLUSION}

The conclusions of the study show that small credit is a mechanism to connect the community members to develop strong social bond support in collective action. The joint effort and communal system built social capital. The small credit system is as an institution where the member participates in improving their socio-economic situation, community-based activities such as economic activities, empowerment activities, Health, and education awareness movements support to poor people to upgrade their quality of life at the grassroots level of development.

However, community members do not use loans in income-generating activities. They are using the loan for another purpose, such as foreign employment, child education, household expenses (Fig.3), which is an inactive sector. These kinds of investments could return and profitable in that case. The discussion point is how do the borrowers repay the loan, and in the context of foreign employment loans have been increasing every year, the question could be microcredit promoting the international migration by providing an overseas employment loan it would be the future research field. The findings support the assumption of the study. The outcome and observation reveal that access to financial services to communities have positive changes. The groups' savings and credit have been expanding the economic mobilization, and expanding the commercial access as well as support in building the capacities of the low-income participants also have positive impacts on the poor 
community.

The research paper concludes that small credit is a vital tool to reduce poverty and urban-rural development. The participants in microcredit 74 'respondent's income are over Nrs 6000, which is double compared to the past (Table 3). The majority of the high-income respondents involve in microcredit over 7 to 15 years compared with past income levels is better than the beginning. The economic access expands the social capital, motivate in collective action through the small credit, gather the scatter community members together for collective action. The financial access support in an empower, and the raised level of awareness compare with the past. The conclusion is, if household women are economically strong, automatically they can be strong psychologically, socially, then they have confidence, and they can participate in different socio-economic and leadership positions and could support in Urban, rural community development.

\section{ACKNOWLEDGMENT}

Concerning those involved in the research, the authorship should be judged appropriately, considering whether to put those collaborators in acknowledgment or put as co-authors. Firstly, I would like to express my sincere gratitude to my advisor and Professors for the continuous support of my Ph.D. The author thanks the local resident of different communities who are as crucial respondents.

\section{NOTES}

Note 1) The multidimensional Poverty identifies how people are being left behind across three key dimensions: health, education and standard of living, comprising 10 indicators. People who experience deprivation in at least one third of these weighted indicators fall into the category of multidimensionally poor. (MPI 2017, UNDP 2019)

Note 2) Community finance is a name of the program of Lumanti where Lumanti organized community-based finance in community level and provided financial services as well as community upgrading activities. CF is similar to microcredit practicing in Asian countries such as Bangladesh, India, and Thailand.

Note 3) LUMANTI is a non-profit making organization established in 1993. It dedicated to the alleviation of poverty in Nepal through the improvement of shelter condition. Since establishment, Lumanti has been focusing its work in the informal settlements and marginalized communities in the cities and towns of Nepal. It focuses on slum upgrading, housing projects, saving and credits, water and sanitation interventions, education program, in the urban and rural area of Nepal with focusing on the urban-rural poverty reduction and community development www.lumanti.org.np.

\section{REFERENCES}

[1] Article: Mayoux, Linda. 2009. "Women's Empowerment and Microfinance: Competing Paradigms." In Microfinance and Women's Empowerment, edited by S Rajagopalan, 29-43. Hyderabad: ICFAI University Press.

[2] Papers: Bateman, Milford. 2014. The rise and fall of Muhammad Yunus and the microfinance international development studies working paper 001.

[3] Book: Aditya Goenka and David Henley (2009) South Asian's credit revaluation: from a money lender to microfinance, Rutledge 1 edition. Rutledge studies in growth, the economies of Asia vol. 63 ISBN 109780415809997.

[4] Book: M.S. Robinson (2001) The microfinance revaluation sustainable finance for reduced, world bank open society institute, Network.

[5] Book: Muhammad Yunus with Karl Weber (2017) the world of three Zeros Hachette publication India.

[6] Overview of Rural Development Issues JICA. https://www.jica.go.jp/jica

[7] Papers: Anne Marie Madeleine Burnside (2011) microfinance in Nepal same-same, but different (Simon foster University)

[8] Papers: Chris D. Gingrich community-based saving and credit and cooperatives in Nepal volume 6 number 1.

[9] Papers: Dean Karlan and Nathanael Goldberg (2011) microfinance evaluation strategies': note on methodology and finding the handbook of microfinance world scientific publication co Pte. Ltd British library

[10] Papers: Dipak Bahadur Adhikari and Jayanti Shrestha (2013) economic impacts of microfinance in Nepal, a case study of the Manamaiju VDC Kathmandu. Economic Journal of development issue vol.15\&16 No 1-2 combines the issue. 
[11] Papers: Eward Yeboah (2017) The impacts of microfinance on grassroots development: Evidence from Smes in Kwabra east district of Ashanti region of Ghana. Open journal of business management 5-577591 https://doi.org/10.4236/ojbm.2017.54050

[12] Papers: Hassan Zaman (2004) Microfinance in Bangladesh Growth, Achievement and lesion A case study from scaling up poverty reduction: a global learning process and conferences Shanghai may 25-27 2004)

[13] Papers: James C. Baru and Gray M. Woller (spring 2004) Microfinance: a comprehensive review of the existing literature -Brigham young university.

[14] Papers: Jeffrey C Alexander (1990) Durkheimian Sociology cultural studies the University of California, Los Angeles paper book ISBN 9780521396479.

[15] Papers: Jonathan Morduch, Barbara Haley (2002) Robert Wagner graduate school of public services working paper series (1014) Analysis of the effects of microfinance and poverty reduction.

[16] Papers: KassaTeshger Alemu (2008) microfinance as a strategy for poverty reduction. A comparative analysis of ACSI wisdom microfinance in Ethiopia, the graduate school of development studies institute of social studies in the Netherlands.

[17] Papers: Naila Kabeer (2001) conflict over credit, reevaluating the empowerment potential of loans to women in rural Bangladesh.

[18] Papers: Phillip H. Ph entrepreneurship and microfinance a review and research Agenda the Johns Hopkins Carey business school Baltimore the USA

[19] Papers: Robert M brook 2008 microfinance for community development, poverty alleviation, and natural resources management in Peri-Urban Hubli- Dharwad India. Environment and Urbanization https://www. researchgate.net/publication

[20] Papers: Sankar man Shrestha (2009) state of microfinance in Nepal (Institute of microfinance) Asian development bank.

[21] Papers: Raja Bali swain Sodertorn university (2007) can microfinance empower women? Help group in India http://www.reserachgate.net/publication

[22] Papers: https://link.springer.com/chapter/10.1057\%2F9781137452993

Citation: Bhakta Kumar Puri, Kazuo Takahashi. "A Small Credit would be an Essential Instrument to Urban-Rural Development". International Journal of Humanities Social Sciences and Education (IJHSSE), vol. 6, no.12, 2019, pp. 42-49. doi: http://dx. doi.org/10.20431/2349-0381.0712002.

Copyright: () 2019 Authors. This is an open-access article distributed under the terms of the Creative Commons Attribution License, which permits unrestricted use, distribution, and reproduction in any medium, provided the original author and source are credited. 